\title{
A ARTE DE DIZER E A ARTE DE CRER: ESTUDO ANTROPOLÓGICO DE NARRATIVA ORAL E SISTEMAS DE CRENÇA NA ILHA GRANDE DOS MARINHEIROS PORTO ALEGRE.
}

\author{
Rafael Victorino Devos
}

\section{Apresentação - A Ilha Assombrada}

\begin{abstract}
"Realidade ou Ilusões: Nós vamos acompanhar algumas histórias que vai arrepiar a muita gente. Os relatos que nós vamos assistir a partir de agora são de moradoras que nos afirmam já terem visto aparições e assombrações, bruxas e lobisomens. E ainda mais: falam de tesouros que teriam sido enterrados, aqui mesmo, na Ilha Grande dos Marinheiros, e que muitos moradores já teriam encontrado muitos desses tesouros.

Você aí em casa, acredita?"
\end{abstract}

Esse depoimento, na verdade, uma fala bem ensaiada e repetida muitas vezes, é um texto que Ricardo, um menino de 18 anos (na época) compôs para introduzir o tema de um documentário etnográfico ${ }^{1}$, produzido a partir de uma oficina de vídeo para adolescentes de classe popular, moradores da Ilha Grande dos Marinheiros, em Porto Alegre. Fruto de um ano de trabalho, essa oficina de vídeo, e a produção desse documentário são a forma como iniciei minha etnografia (como professor da oficina) entre os moradores da ilha².

Hoje, já não sou o "professor", nem pesquiso em conjunto com a equipe que realizou o vídeo (moradores da ilha e colegas de pesquisa em antropologia visual). Meu tema de pesquisa se desenvolve junto a velhos moradores da ilha, entre uma memória das transformações espaciais da ilha e o acompanhamento de suas práticas cotidianas. Parte dessa memória, e desse cotidiano, essas histórias “de arrepiar" continuam sendo recorrentes nas conversas do campo, e há mesmo um prazer (não só do pesquisador, mas dos narradores) em dar um lugar destacado a essas histórias nas conversas.

A partir de algumas reflexões surgidas com a disciplina de "Religião e Sociedade", da qual participei no Programa de Pós-Gradução em Antropologia Social

\footnotetext{
${ }^{1}$ Documentário "Ilha Assombrada - Realidade ou Ilusões?", produção do Banco de Imagens e efeitos visuais, PPGAS - UFRGS, 1999/2000.

${ }^{2}$ Essa reflexão que trago aqui, portanto, é fruto da parceria com a orientadora Ana Luiza Carvalho da Rocha, com os hoje jornalistas Alfredo Barros e Silvia Cavichioli durante o trabalho da oficina como parceiros na difícil tarefa de ser professor, e também do trabalho com os alunos da oficina durante as
} 
da UFRGS, muitas das práticas e sistemas de crenças de meus informantes começaram a ter maior relevo no contexto da pesquisa.

Proponho aqui uma reflexão primeira em torno do conteúdo das histórias, de alguns temas recorrentes, com os sistemas de crença aos quais se encontram relacionadas as pessoas que narram essas histórias. Catolicismo popular, espiritismo kardecista, pentecostalismo se encontram então com as assombrações, com os lobisomens, com as bruxas, e outros.

Num segundo momento, proponho uma reflexão em torno da crença enquanto prática, relacionada com a trajetória religiosa dessas pessoas (e seus "usos da fé"), de encontro a prática da narrativa oral, da tessitura da narrativa, do próprio fazer que envolve não só a prática das formas modernas de crer, mas também da arte de narrar.

Minha intenção, devido ao fato do presente estudo ser fruto de uma etnografia ainda em andamento, não é tanto formular grandes conclusões, mas buscar novas possibilidades de reflexão, a partir do pensamento antropológico sobre o tema da religião, junto a estudos de performance e narrativa.

\section{O Lugar das histórias}

Escândalo na televisão: um canal de televisão a cabo local exibia uma matéria sobre a Ilha Grande dos Marinheiros. Na parte de mais difícil acesso da ilha, sem infraestrutura de esgoto, água e luz, pessoas sobrevivem no escuro, isoladas e, horror dos horrores, "bebendo água diretamente do rio". Outra imagem famosa da ilha: o premiado Curta Metragem "Ilha das Flores"3 que traça o trajeto de um tomate, desde a sua produção, na passagem pelo supermercado, passando pela casa de uma família de classe média e chegando a chamada Ilha das Flores (na verdade, filmado na Ilha dos Marinheiros), onde o que sobrou do tomate é jogado em meio ao lixo como comida para os porcos, e o que sobrou da refeição dos porcos é dado como refeição à "seres humanos" moradores da ilha. Imagem contrastante: Laci, 72 anos, filha de pequenos agricultores, viúva de pescador, mãe de 12 filhos ("morreram treis") metro e meio de altura, caminhar cambaleante ("eu tenho as perna meio cambota"), sai da Assembléia de Deus, em um final de tarde, indo para casa terminar o serviço de costura, antes de ir pro "colégio" aprender a escrever o nome do lugar em que nasceu: M-o-r-r-e-t-e-s.

nossas andanças pela seu lugar que passou a ser mais familiar para os professores, e mais estranho para eles.

3 "Ilha das Flores", filme curta-metragem em 35mm, produção da Casa de Cinema de Porto Alegre, direção de Jorge Furtado e Zé Pedro Goulart, 1985. 
A Ilha Grande dos Marinheiros é, ao mesmo tempo, parte de um bairro da cidade de Porto Alegre, o Arquipélago, e parte de uma reserva ambiental do Rio Grande do Sul, o Parque Estadual Delta do Jacuí. Nessa dupla particularidade reside a maneira também ambuígua como a ilha é conhecida. Enquanto bairro da cidade, a Ilha Grande dos Marinheiros é conhecida pela ocupação que apresenta por pessoas de baixíssima renda e de condições precárias de vida . O "pessoal das ilhas”, nas vilas de papeleiros, carroceiros, catadores de lixo, biscateiros, empregadas domésticas, são algumas das pessoas que costumam aparecer nos jornais associadas as tragédias de enchentes (como a recente, do mês passado, maior dos últimos dez anos), criminalidade e principalmente a presença dos muitos depósitos de lixo que seus moradores trazem da cidade. Essa ocupação é tensionada por sua presença na área do Parque Estadual do Delta do Jacuî́, que restringe as áreas de ocupação das ilhas, e busca resguardar sua função de "filtros naturais, indicadores de poluição dos rios que as banham, reguladoras do clima e controladoras de cheias."

Ocupada por grupos de baixa renda e por alguns sítios de lazer de alta renda, a Ilha Grande dos Marinheiros, em conjunto com as demais ilhas, guarda na sua paisagem a memória de uma ocupação de suas terras, anterior à constituição do Parque do Delta, por grupos populares de pescadores, barqueiros, pequenos proprietários rurais, criadores de porcos e gado leiteiro, que consistem na figura do que o próprio plano de consolidação do Parque chama de "ilhéu". No entanto, essa noção de "ilhéu", essencializando um suposto personagem das ilhas, acaba "ilhando" a relação que muitas das pessoas que já moram há bastante tempo na Ilha dos Marinheiros sempre possuíram com a cidade de Porto Alegre, nos seus deslocamentos e nas suas relações de trabalho. São freqüentes as histórias de pescadores que trabalharam como operários em fábricas, empregadas domésticas de "casa de família" na cidade, "embarcados" que trabalharam para a indústria naval, assim como são freqüentes as histórias de pessoas que se deslocaram do interior do Estado para as ilhas, das ilhas para a cidade, da cidade para as ilhas, de ilha para a ilha, e dentro da própria ilha, de um lugar para outro.

Apresento a Ilha Grande dos Marinheiros, portanto, como uma ilha, no sentido das práticas presentes no seu cotidiano e nas suas relações simbólicas com a paisagem de matos, pântanos e beiras de rios e proponho o estudo da memória dessa paisagem,

4 “Consolidação do Parque Estadual Delta do Jacuí - reavaliação das condições sócio-econômicas da população e situação atual de ocupação e uso do solo do Parque", Pró-Guaíba e METROPLAN, Governo do Estado do Rio Grande do Su, 1999. 
entendida não como uma paisagem "natural", como sugere a lei ${ }^{5}$ que decreta o Parque, mas como uma paisagem que é uma construção humana, no sentido que Simon Schama propõe:

"E, se a visão que uma criança tem da natureza já pode comportar lembranças, mitos e significados complexos, muito mais elaborada é a moldura através da qual nossos olhos adultos contemplam a paisagem. Pois, conquanto estejamos habituados a situar a natureza e a percepção humana em dois campos distintos, na verdade elas são inseparáveis. Antes de poder ser um repouso para os sentidos, a paisagem é obra da mente. Compõe-se tanto de camadas de lembranças quanto de extratos de rochas."

Sendo construção humana, com "camadas de lembranças", apresento a Ilha Grande dos Marinheiros igualmente como uma paisagem urbana, transformada pela ação humana, pelos deslocamentos das pessoas, por suas relações com os processos de domesticação e modelação do espaço urbano. Entendo esse espaço, na idéia de Michel de Certeau, de um lugar. Um lugar que implica em um nome, em uma apropriação, em uma forma de habitar, de transitar, de deslocar-se e assim transformar o espaço "planejado" da cidade (e de Parques Estaduais):

"O memorável é aquilo que se pode sonhar a respeito do lugar... Mas, como já se viu, este ser-aí só se excerce em práticas de espaço, ou seja, em maneiras de passar ao outro."7

É no contexto de um contar da memória das transformações espaciais ocorridas nas ilhas, e de seus deslocamentos por elas, que as narrativas de aparições e assombrações “aparecem”:

“Há uns anos atrás, eles traziam os escravos da cidade, a remo, né? Eles traziam dois, três, escravo, branco, preto, os coitado. E depois, enterravam o

\footnotetext{
5 “Consolidação do Parque Estadual Delta do Jacuí - reavaliação das condições sócio-econômicas da população e situação atual de ocupação e uso do solo do Parque”, Pró-Guaíba e METROPLAN, Governo do Estado do Rio Grande do Su, 1999.

${ }^{6}$ SCHAMA, 1996:17

${ }^{7}$ CERTEAU, 1998:190.
} 
dinheiro e matavam eles pra eles cuida o dinheiro. Aí aqueles espírito ficava alí. Porque o espírito não morre. O espírito não morre nunca. Fica vivo.”

(Laci - Ilha Grande dos Marinheiros)

“Diz que há muitos anos foi cemitério. Eu acredito porque inclusive lá na prainha tudo aquilo que as pessoas foi encontrar e pra lá pra aqueles lados tudo é assombrado, geralmente todas as casas pra lá tudo é assombrado."

(Maria - Ilha Grande dos Marinheiros)

“... aqui no fundo dessa igreja era um cemitério, candestino, clandestino. Sei que matavam as pessoa no tempo da guerra, da guerra e enterravam por aqui... Até tinha um homem que aparecia aqui na cerca. Mataram o homem e enterraram, na, bem no nosso portãozinho, que nós tinha pra lá. Nessa casa dos fundo tinha uma cerca e nós ia pro vizinho. E aparecia o homem ali. Então dizia o vizinho assim - não tem medo, irmã Geni? Eu não, medo do quê? Qual é o mal que ele vai fazê pra gente? Mal nenhum. Tenho medo é dos vivo, não dos mortos.

(Geni-Ilha Grande dos Marinheiros)

Esse depoimento de "irmã Geni", refere-se ao local onde hoje encontra-se a sede da Assembléia de Deus, na Ilha dos Marinheiros. Geni, 70 anos de idade, moradora da ilha há mais de quarenta anos, cuida da Igreja que o falecido marido construiu no quintal da sua casa, para onde mudou-se a igreja da Assembléia que ficava "no fundo da ilha”. Conheci Geni na Igreja, num culto realizado aos sábados, por meio de irmã Laci, outra "crente" assídua da Assembléia na ilha. Durante a entrevista, me surpreendi com as histórias de assombrações e lobisomens que Geni contava, nesse caso, da assombração que "aparece" ligada a fundação da sede da Assembléia de Deus, e que é semelhante a outras figuras assombradas que aparecem na fala de pessoas ligadas a outros sistemas de crença, e que eu, então, achava que eram coisas difíceis de ouvir de um crente evangélico. No caso dessa história, Geni tece sua explicação:

E como é que ele era, assim? - Era homem,é... assim..., era o inimigo, era o Demônio, assim, a gente, não volta mais aqui, era o demônio, aparecia pra assustá as pessoas. O demônio, inimigo da alma da gente. - Bem na Igreja, aqui, né? - Sim, não tinha nada aqui, era cemitério, matavam as pessoa, de guerra, e enterravam aí. 
A minha surpresa, foi a de perceber que na fala dos informantes, com sua diferentes "formas de crer" que pude ter contato na "Ilha Grande", como pentecostalismo ("Assembléia de Deus e Igreja Universal do Reino de Deus), catolicismo popular e espiritismo, as histórias de bruxas, de lobisomens, de desenterro de tesouros, de assombrações apresentavam uma estrutura recorrente. Ainda que interpretadas, explicadas (por vezes reduzidas) a partir de cada sistema religioso, no momento do tecer da narrativa, do contar da história, no desenrolar do relato da memória, a impressão que eu tinha era a de que um mesmo fundo semântico, um mesmo sistema de idéias "aparecia" ligado a essas histórias.

\section{SABERES}

\subsection{As formas de crer}

Quando falo aqui de religião, entendo religião no sentido colocado por Oro:

"uso o termo religião num sentido amplo, enquanto um sistema de crenças, de práticas, que confere às pessoas sentido para a existência, duradouro ou passageiro, implícita ou explicitamente; propõe-lhes a "salvação" .

O conhecimento que tive da religião na Ilha Grande, tive acesso a partir das práticas de alguns informantes. Não procurei aprofundar a etnografia de nenhum grupo em particular, e, para não procurar contradições entre o que dizem e falam os informantes e o que estabelece a doutrina de cada sistema, procurei entender a crença, como propõe Michel De Certeau:

“... entendo por "crença" não o objeto do crer (um dogma, um programa, etc), mas o investimento das pessoas em uma proposição, o ato de enunciá-la considerando-a verdadeira noutros termos, uma "modalidade" da afirmação e não o seu conteúdo..."

“... o investimento do crer passa de mito em mito, de ideologia em ideologia, ou de enunciado em enunciado." $" 9$

\footnotetext{
${ }^{8}$ ORO, 1997: 42.

${ }^{9}$ CERTEAU, 1998: 278.
} 
Procurei, também, pensar a idéia de um campo de trocas religiosas entre as pessoas que circulam pelas ilhas, trocas em que essas narrativas a que me refiro ocupam um lugar central. No sentido do que sugere Brandão, em "Os Deuses do Povo":

"Em conjunto, vimos que as religiões dizem mais ou menos as mesmas coisas. O ponto de partida comum a todo o corpo de representações do sobrenatural - originado de espaços vizinhos de um mesmo setor de cultura - é o que torna tão intercambiáveis a lógica e os repertórios de crenças de todas as religiões, sobrepondo à variança um mesmo modo social de imaginar o sagrado. Ali é onde o pastor pentecostal, para pensar contra o médium do saravá, precisa partir dos seus princípios e, primeiro, pensar como ele."

Própria das "formas modernas de crer" essa reelaboração de algo já existente, em que cada indivíduo tende a moldar a própria religião, combinando elementos de biografia, de momentos da vida cotidiana, de identidade e dos problemas com que lidam os sujeitos no seu cotidiano moderno. Assim, "a ênfase recai, pois, mais sobre as crenças e práticas dos atores do que sobre os sistemas religiosos, embora os dois lados estejam, de alguma forma, sempre implicados entre si."

Conversando com Laci sobre o documentário, que havia sido exibido na televisão, ela me dizia da reação de seus companheiros de Assembléia de Deus quanto as histórias que ela conta no vídeo: "Eles diz que não existe, que é coisa do, do capeta. Mas eu sei que é verdade.".

“Eu, quando morava no Furadinho. O Furadinho é quase lá. É chão até lá. Lá é divisa, quase divisa com Morretes. E lá, nós morava lá, tinha. Tinha um dinheiro lá. E eu tava pra ganhar um filho meu. Aí eu tive um sonho. Quem tava dando o dinheiro pra mim era um padre. Ele tava de branco, com a roupa branca e aquela bata. Bata, assim. Aí tava com as mãozinha pra trás e disse assim - Eu te dou esse tesouro pra ti. Aquela figueira que tá lá, diz que tá lá até hoje. Não fui mais lá. Depois que nós se mudemo, não fui mais lá. Aí disse - Pega ali e arranca. Isso, que no sonho eu arranquei, assim, tinha uma raiz assim, pro lado do nascimento do sol. Eu fiquei faceira, juntava o dinheiro e juntava no vestido e botava debaixo da cama. Mas ele pediu um filho meu, que eu tava pra ganhar nenê, que ele queria aquele guri pra ele, aquela criança. E eu disse que não dava. No sonho. Isso é sonho. E tinha um coqueiro na beira do rio, também, que o mesmo padre me deu pra mim. E, que era um tachinho, igual uma rapadura. E eu me iludi com aquilo. E acho que aquilo, a criança nasceu e morreu, no mesmo mês. E o meu velho disse - Isso aí é impossível. Aí ele chamou umas pessoa que entendia disso aí, na cidade, vieram pra ilha e

\footnotetext{
${ }^{10}$ BRANDÃO, 1986: 295.

${ }^{11}$ ORO, 1997: 41.
} 
tiraram o dinheiro. Depois que nós saímo, tiraram o dinheiro. Diz que era uma riqueza."

\subsection{Histórias de crentes}

Laci, 77 anos, é crente da Assembléia de Deus. Já acompanhava a Igreja antes de se mudar para a Ilha, quando morava no bairro Navegantes, do outro lado da ponte que liga as ilhas a Porto Alegre. Sua conversão se deu em função de uma filha, que ficou um ano no hospital, com queimaduras, resultado de um acidente em casa. Para salvar a filha “do fogo”, Laci prometeu se entregar para Jesus, e se entregou. Virou crente "depois de velha", quase com cinquenta anos. Antes, pouco ia na Igreja "do padre” (católica), quando morava em Navegantes, e apenas acompanhava o marido, que benzia e entendia “dessas coisa”, um pescador de Morretes, antiga vila de pescadores, próxima à Ilha Grande. Agora crente, não consegue ler ainda a Bíblia, é semi-analfabeta, mas já está cuidando disso, participando, já há três anos, de um curso de alfabetização de adultos na ilha. Seu engajamento com a Igreja se dá na prática dos testemunhos, em que várias vezes se vale de sua história de vida como fonte de ensinamentos, nos cantos com o coral, do qual participa e nas visitas as pessoas que precisam de oração, que faz junto com as companheiras. Participa de várias das atividades da Igreja, indo no mínimo quatro vezes por semana à Assembléia, dedicando o resto do seu tempo a família (três filhos, já adultos, moram com ela) e à atividade de costura, com a qual tira um dinheiro extra, e ao mesmo tempo ajeita e organiza roupas para “as pessoas pobre”, mais pobres que ela.

Geni, 70 anos, "era uma pecadora”. Bebia, fumava e negava a Igreja, a Assembléia de Deus, da qual participavam seus pais e irmãos. Negou até que foi curada pelo espírito santo:

"Fui curada da lepra, fui curada da Úlcera no Estômago, ... fui curada de muitas doença, na igreja, né, quase antes de eu ser, de eu me batizar, na véspera de eu me batiza eu fui curada das doença e, eu, tinha trinta e um ano que eu era leprosa. Minha família já arrumando a baixa pra me botá lá no Partenon, no leprosário. E depois de cair lá, meu filho...”

Salva das doenças, Geni se batizou para poder casar (na véspera do casamento). O marido foi um dos primeiros a cuidar da Igreja na Ilha. Perambulando pela ilha, (a Assembléia de Deus já teve várias localidades na ilha), Geni trabalhou para a igreja, saindo com “dois liquinho na mão e uma sacola de bíblia nas costas” para preparar a 
igreja para quando o marido chegasse do serviço, para começar o culto. Hoje vive como uma espécie de "caseira" da nova sede da Assembléia, que já é dirigida por outras pessoas. Assim como Laci, ainda mantém a prática de circular pela Ilha, ainda que com dificuldades para caminhar, para levar a palavra de Deus às pessoas "pobres".

Cláudio é um pescador, aposentado, de 56 anos, nascido na Ilha Grande, que já morou em muitas das ilhas que compõe o Parque do Delta do Jacuí. Me contou de quando andava de barco pelos cantos desconhecidos dos rios, em noites de lua cheia, das coisas que via e que aconteciam, "antes de entrar pra igreja”, aos 29 anos de idade. Vivia com a mãe que era "espiritista”, kardecista. Se converteu por causa do filho, no tempo que a igreja ficava na parte "de cima" da ilha, onde mora. Depois de feita a entrevista, soube que Cláudio já foi, inclusive, pastor responsável por muitas atividades da igreja na ilha. Agora, está mais afastado, indo com menos frequência por ter que cuidar da mãe que está doente, de cama, na velhice.

\footnotetext{
"Essas ilha aqui tem muita coisa enterrada, do tempo das guerra. Eu agora eu sô crente, so religioso, so dá Assembléia de Deus, aqui, a gente vê, pelas escritura as coisa, né? Mas naquela época assim, eu cria, muitas coisas eu acreditava assim, né? Ainda tem coisa que eu acredito ainda. A minha mãe teve três sonhos, três noite, a seguida, ela teve treis sonho que chegava um rapaz, e uma mulher, nela e dizia tu vai cava embaixo daquele angazero, tinha um pé de angazero, esse que tem na bera do rio, aí tu leva uma bacia que tu vai acha ouro pra ti lá. Mas tu vai sozinha, na ponta de pé, a noite. E a minha mãe sempre com medo, né? Tu vai acha uma luz, que tá lá. E a minha mãe não foi, as três noite ela não foi. Aí diz que foi pruma otra vizinha lá em baixo, a mulher crio coragem, foi lá e acho. Acho. Uma bacia, cheia de moeda de oro e de prata, uns patacão assim, ó, e bem na flor da terra, no pé da árvore, uns dois palmo assim... Aqueles espírito eles tavam preso, por aquilo ali. Por que a bíblia diz que a riqueza é bom, pra quem sabe usá, mas quem não sabe usá ela se torna uma prisão pra pessoa. Então o que que aconteceu: enterro, e aquela pessoa morre e fica em volta daquilo, ela não se liga na vida melhor que tem ao redor dela."
}

Todos os três, a irmã Laci, a irmã Geni, e o pastor/pescador Cláudio pertencem ao grupo de pentescostais evangélicos (no caso, da Assembléia de Deus) da Ilha Grande dos Marinheiros, onde encontram-se fiéis, em maioria, da Assembléia de Deus, com sede na própria ilha, na Ilha das Flores e na Ilha da Pintada. A modesta construção ao lado da casa de irmã Geni, próxima a faixa da BR 116, na entrada da ponte que vai para Porto Alegre, quase em frente a parada de ônibus do "Ilha da Pintada", ocupa um lugar estratégico, e atrai um público de todas as ilhas, dos municípios de Guaíba e Eldorado nos cultos principais, e ainda de pessoas vindas de bairros próximos, como o bairro Navegantes e uma parte de Canoas. A outra igreja evangélica que possui muitos fiéis no 
bairro Arquipélago é a Igreja Universal do Reino de Deus, cujas sedes mais próximas encontram-se no centro da cidade e na Ilha da Pintada. É comum ver os crentes não apenas na igreja, mas na parada de ônibus, no fim da linha do ônibus em Porto Alegre, ou mesmo em missão em caminhadas pelo interior da ilha, pela ponte e pelos bairros próximos a ela levando a palavra do senhor aos pecadores.

Nos relatos de Cláudio, Laci e Geni, é possível se perceber que a sua trajetória religiosa, de aproximadamente trinta anos acompanhando a Assembléia de Deus, demonstra que a ocupação da Ilha Grande, que é recente em termos de crescimento populacional $^{12}$, desenvolveu-se em conjunto com a instalação da Igreja da Assembléia de Deus, há quarenta anos, tendo migrado da zona de caráter ainda rural, de pequenas propriedades na parte mais ao norte da ilha (mais povoada quando não existia a ponte), para a proximidade da BR, zona mais "urbana" da ilha, núcleo denso de população. A Assembléia de Deus, fundada em 1911 no Brasil, em Belém do Pará, por missionários Suecos ${ }^{13}$, surgiu já voltada para as camadas empobrecidas da população. Forma seus funcionários (e todos os três aqui citados podem ser considerados funcionários) pela prática da pregação, e muitos desses funcionários são pessoas da própria comunidade. Entre as práticas, estão a oração, íntima, mas realizada na exclamação dos sentimentos de louvor a Deus (“Aleluia! Glória, glória...), o estudo da Bíblia nas escolas dominicais, a pregação pela palavra do senhor, ou pelo testemunho próprio das graças alcançadas, as ações evangelizadoras nas ruas, as realizações dos dons do Espírito Santo (falar em línguas estranhas, profetizar, curar pela palavra, expulsar demônios), o também Dom do Espírito na música, com corais e bandas evangélicas, batismos (“descer as águas”), casamentos (geralmente dentro dos próprio grupo) ${ }^{14}$. A comunidade religiosa da Assembléia de Deus é de uma lógica sectária, de divisão do mundo, segundo Brandão:

"O nós reune os que possuem a verdade religiosa sem o poder terreno, contra um eles dos que possuem o poder terreno sem a verdade religiosa. Este eles está dividido entre a minoria dos agentes rivais a evitar e a massa dos subalternos a conquistar." 15

\footnotetext{
12 “Consolidação do Parque Estadual Delta do Jacuí”, 1999.

${ }^{13}$ ROLIM, 1990: 47-53.

${ }^{14}$ FERNANDES, 1998.

15 BRANDÃO, 1986: 143. "Assim, a igreja pentecostal separa os seus membros do mundo com a condição de criar para eles um mundo separado, não só do ponto de vista ético (o crente não fuma, não
} 
Na fala da irmã Geni:

E a Sra conheceu seu marido na Igreja? Na Igreja. Não era crente quando eu conheci ele. Depois que eu conheci ele que eu deixei de vício e tudo mais que eu tava. Me batizei e me casei. Com trinta e nove ano, quase quarenta. Então ele teve um papel importante aí? Lhe convenceu? É. E eu não queria casar. Queria seguir a Deus pra ir nas excursão com os irmãos, né? Eu achava tão bonito assim, meu irmão saía, aqueles ônibus cheinho de irmão, pra fora, nas excursão. Bem longe. Eu dizia eu vou segui a Deus pra sair com os irmão. Depois que eu me casei que eu fui pra Igreja, me casei, saí só em duas excursão. Uma pra Morretes e otra pra Capão da Canoa.

Nesse "nós", que implica num saber e num poder do crente pelo conhecimento do sagrado, é possível distinguir nem tanto um mundo à parte, mas um universo simbólico, um conjunto de representações e práticas, dividindo temas, valores, vivências e preocupações semelhantes. Uma rede de relações, própria da heterogeneidade da experiência cultural em sociedades complexas ${ }^{16}$, como Porto Alegre. E em contextos populares, numa comunidade onde as redes de vizinhança são fortes, onde as pessoas dividem os mesmos espaços, os mesmos itinerários em direção aos espaços da ilha e da cidade, onde as trocas se dão. E muitas dessas trocas, são trocas religiosas, onde as assombrações, os tesouros, os lobisomens e outros mistérios são temas recorrentes. Para o evangélico, o jeito é "multiplicar os demônios", como coloca Brandão:

"Os pentecostais de barracão condenam a maneira como
os católicos e os mediúnicos "de baixo" e "de cima"
convivem com seus mortos. "Deixai que os mortos
enterrem os seus mortos", eles dizem com frequência,
citando a palavra de Cristo no Evangelho... O que os
presbíteros e os seus auxiliares negam com mais empenho
é que qualquer forma de espírito dos mortos possa vagar
pela Terra e possa "Ter comércio com os vivos". Mas,
como é difícil negar a evidência de aparecimentos de
assombrações ou a "descida" de espíritos nos terreiros, os

bebe, não adultera, não fica em bar, não vive pelas ruas, não vê televisão, não vai ao cinema, não escuta rádio), como do ponto de vista de uma rotina de vida. "Fora de casa e do trabalho, lugar de crente é na Igreja", ou é nos círculos onde a cultura da igreja estende-se pela vida de cada crente. Um adepto fervoroso tem cultos às quartas, quintas, sábados e domingos; tem escola dominical, ensaios de coro ou de banda, jornadas de pregação em culto ao ar livre, visitas aos "irmãos doentes", visitas proselitistas à vizinhança, excursões "da igreja" para cultos em outras cidades.... Ao contrário do que poderia parecer, para o crente "separado do mundo" esse envolvimento com "a Igreja" é festivo e essa festa é sempre uma situação fortemente afetiva.".

${ }^{16}$ VELHO, G. 1981: 21. 
agentes evangélicos afirmam que: "Tudo isso não passa de arte do Demônio..."17

Quando Brandão, fala do "lugar social do morto" em diferentes sistemas de crença, aponta que a religião evangélica, pentecostal, estabelece uma separação rígida entre o bem e o mal, entre três sociedades distintas: na Terra, no Céu e no Inferno. O mundo terreno e profano é visto como campo de batalha dessas forças, onde os demônios vagam em busca da condenação da alma, onde os crentes lutam pela sua salvação. Já nas religiões ditas "mediúnicas”, espíritas kardecistas, umbandistas, e praticantes de candomblé, ou batuque (no caso de Porto Alegre) essa separação é menos tenue, seres sobrenaturais como os orixás, ou espíritos, esclarecidos ou não, perambulam por todos os mundos, interferindo, atrapalhando ou auxiliando, obcediando ou iluminando os caminhos dos vivos. E já no catolicismo, nem tanto o "erudito", mas o catolicismo popular, todas as relações e combinações são possíveis, entre sujeitos terrenos ou sobrenaturais, celestiais ou infernais..

É assim que, mesmo com a roupa do demônio, esses orixás, espíritos, anjos, bruxas, lobisomens, almas-penadas, santos, serão personagens de narrativas entre crentes pentecostais. E são personagens porque, aguardando na memória o momento de entrarem em ação, engendram na narrativa uma forma de conceituação simbólica daquilo que seu narrador realmente viveu, quando já era, ou ainda não se convertera em crente, transposto para os muitos saberes das religiões, tomadas em conjunto, num todo onde um saber erudito, classificatório, só veria contradição, "bricolagem desordenada" "18 , um todo de significação a partir do lugar e da circunstância do contar da história. Transcrevo aqui uma narrativa do pastor (e pescador) Cláudio, antes de entrarmos em contato com os demais narradores e suas outras práticas religiosas:

\footnotetext{
“Mas tudo essas coisa assim, bruxaria, são pessoas usada pelo diabo. Ruins, mesmo. Ruins. Então o que acontece: ela faz mal para os outros. Uma bruxa, que fez mal pra mim, uma bruxaria. Mas ela trabalha com o demônio. Eu conheci pessoas assim. Eu era guri, cuida bem: uma história verídica que comigo aconteceu. Eu tinha oito ano de idade, pra nove. E na ponta dessa otra Ilha do Pavão tinha uma negrona, era batuquera. Ela tinha uma filha que também regulava comigo, com a minha idade. E então essa guria, na época eu era bobão, e essa guria queria caso comigo. Assim, caso de criança,
}

17 BRANDÃO, 1986: 190.

18 "Um sistema de crenças é parte de uma ideologia, ou seja, de uma representação social de mundo que lhe dá sentido e faz com que um repertóprio de afirmações sobre os mais diferentes objetos de conhecimento tenha uma loógica e uma estrutura sistêmica, no lugar onde só um exame apressado pode concluir quew ali existe apenas uma bricolagem de saber desorganizado." BRANDÃO, 1986: 221. 
namorico. E eu assim - Vai pra lá, ô negra batuquera, negra batuquera, eu chamava negra batuquera, chingando. Fico por isso mesmo e essa guria me levou até a casa dela, e a mãe dela me fez uma coisa pra mim, me jogou um negócio lá pelas costas, lá. Fez lá uma macumbaria, e eu caí de cama. Rapaz, eu caí de cama, e a minha mãe na época, ela era espiritista, ela era kardecista. E aí caí de cama e fiquei na cama mal e mal, e levei em médico, nada. Não teve remédio que adiantava e eu minguei assim que... Aí um dia minha mãe pegou assim a ir nessa casa dela de espiritismo, e quando foi uma certa noite, aquele espírito pegou a minha mãe, aquele espírito, dentro de casa. E aquele espírito dizia assim na boca da minha mãe, falando: ela pegou a assobiar, espernear e aqueles espírito dizia assim: ah, nós semo aqui uma turma de nove. E o meu pai falando - o que tu qué? Ah, o teu fio ofendeu a Tilde, a família da Tilde. Falando, assim, na boca da minha mãe. E o meu pai, mas não faça isso, e dando conselho, e os meus irmão pulavam da cama dessa altura assim, o meu pai tranco os dente, um esculhambação. E aquele espírito dizia assim, nós semo nove e só eu que tive coragem de entrá aqui dentro, os otro tão aí fora, falando com o meu pai, né? Tão aí fora. E o que que vocês ganham com isso aí? Ah, nós temo aqui por um buquê de flor, nós temo por uma vela, nós temo por um tostão, nós temo por um prato de comida, bem assim, falando. Aí meu pai começou a aconselhar, que ele era espiritista também, na época, né? Os espírita até são umas pessoa boa, os Bezerra, tem uma época até que eu gostava, conhecia. Eu só não gosto que eles invocam muito os espírito... Então, continuação da história. E o meu pai aconselhava, e tal e aquele espírito ficou bom, assim, bote meu nome lá, naquela casa... Lá onde tem aquela água, tem um bruto, só vocês não contem pra Tilde, senão ela vai dá uma tunda em nóis, e naquele lugar que voceis enche a água - que nós enchia água do lado de cá, tomava água do rio, não tinha água encanada - lá tem um bruto, lá. Aí no otro dia minha mãe se levanto, fomo lá vê o que que era, tinha uns feitiço assim, tudo enrolado, tinha ropa minha, tinha um otro saco tinha três pexinhos, quando os pexinho morresse, eu morria também, entendeu? Mas ninguém mata ninguém, a não ser que Deus permita. Deus tinha plano pra mim, Deus tem plano pro senhor... É como Eliseu ....na Bílbia..."19

\section{3. "Sozinha...... e Deus."}

Maria é uma senhora de uns setenta anos de idade, que hoje mora na Ilha das Flores, mas já morou na Ilha Grande dos Marinheiros, na Cidade Baixa em Porto Alegre, numa construção na Carlos Gomes, no Dique (margem do Guaíba próxima a ponte, na saída da cidade). Nasceu em Bagé e veio pra cidade com o marido. Trabalhava de empregada doméstica em "casa de família" e hoje é aposentada com a pensão do marido. Foi na cidade que aprendeu a benzer. "Benzê um ar na vista, cobrero, bichinho na boca, eu benzo, de bom coração...". Frequienta o centro espírita dos "bezerra" na Ilha Grande dos Marinheiros, a Igreja Universal do Reino de Deus, na Ilha da Pintada (onde

\footnotetext{
19 "Creio que a "guerra religiosa" se coloca basicamente em nível institucional, de conquista de território e de "almas". Mesmo em relação à Igreja Universal do Reino de Deus e sua luta contra os cultos afrobrasileiros, mais do que uma lógica de exclusão, é a lógica da inclusão que preside as ações. Muitas
} 
o neto é "obrero"), vai em Igreja católica, em Porto Alegre, faz um pedido pra Nossa Senhora Aparecida ${ }^{20}$ no santuário na Ilha dos Marinheiros e percorre outras "igreja" onde é "fichada pra ganhá os meus auxílio". Escuta a palavra pentecostal na Igreja Universal, crítica a conduta de alguns crentes que "faiz coisa errada" e benze o neto obreiro da Igreja Universal, com “treis galinho verde”. Vai na Igreja dos bezerra atrás de doações materiais e conselhos espirituais:

\begin{abstract}
"Depois que eu comecei a frequenta firme a igreja dos bezerra, ali, eu ouvia as voz me chama, de manhã. Umas três vez, eu ouvi chamá: Mariiiiia.... Ah, eu me acordava assim, surpreendida, né? ... Nos bezerra, Sábado, eu vô falá lá pro irmão da igreja o que que é. Que eu vejo essas voz... Aquela voz de longe, mas era na frente da minha casa. Parece que vinha entrando assim, no corredorzinho, pra me chama. Depois eu comecei, falei pra eles, aí disseram que eu tinha que ora bastante, bota o livro tudo. Eu comecei a fazê aquilo que eles mandaram, com fé, né? Bastante fé, que fé sempre eu tive, né? Mas a gente tem que, segui eles, eles que sabem mais que nós, né? Que eles são de Igreja, né?"
\end{abstract}

Maria poderia situar-se entre os agentes populares religiosos de que fala Brandão

"O trabalho recriador de rezadores, capelães e agentes de cura transfere, sem quebrar a lógica, os símbolos e as combinações de uma mesma tradição cultural de fé. Dentro dela, livre das amarras da Igreja e de suas confrarias de burocratas fiscais, desde que não desrespeite os princípios de invenção das representações populares, cada agente de qualquer comunidade pode acrescentar os casos próprios do estoque local a um repertório comum de crenças." 21

Maria professa antes sua fé do que uma doutrina para crer. Se insere numa tendência característica do catolicismo popular tradicional, como coloca Steil, para

“... incorporar, integrar e juntar elementos de diversas tradições ou fontes, compondo sínteses personalizadas de crenças com um mínimo de intermediação institucional. Esta tendência se contrapõe à lógica que opera nos

análises da IURD têm mostrado que grande parte do seu sucesso se deve à incorporação da linguagem e do panteão afro-brasileiro em seu universo discursivo.” STEIL, 1999:95.

20 "Eu acredito muito na Nossa Senhora Aparecida. Eu gosto muito da Nossa Senhora Aparecida. E às vezes, essas coisas que eu faço, que eu peço pra ela. Até inclusive tem aquela santinha ali, na beira ali. Eu compro um pacote de vela, umas flor bem bonita lá no centro. Eu venho ali quietinha, não digo pra ninguém. Chego lá, rezo. Acendo aquela velinha, boto aquela flor, ofereço pra ela, olho bem pra ela e peço, agradeço pra ela. Ai! Saio tão feliz, parece que eu tô, parece que eu não tô nem pisando no chão, saio tão feliz, tão feliz. E vô pra casa, tô, tão contente."

${ }^{21}$ BRANDÃO, 1986: 204. 
sistemas mais racionalizados, onde predomina a tendência, para restringir, separar e analisar, tendo a instituição como árbitro." 22

Entre todas as entrevistas, a narrativa de Maria foi a que desfiou o maior número de histórias, de causos, de "coisas" que aconteceram. Remontando sua trajetória de deslocamentos, das dificuldades por que passou ("bastante trabalho aqui nessa ilha, nós era bem pobrezinho...”), dos dois filhos que criou entre os doze a que deu a luz, se segura na força da fé para carregar a sua "cruz". Nos relatos sobre embruxamento de crianças, por vezes, um saber popular, filiado a um catolicismo popular de origem açoriana $^{23}$,era perceptível, por vezes, qualquer tentativa de enquadrar seu conhecimento em algum campo definido fazia o mesmo saber migrar para outras fronteiras simbólicas.

\begin{abstract}
Ah! As bruxa? Sabe o que quelas fazem? As bruxa pegam as criança, porque inclusive eu tinha, eu já perdi filho embruxada, uma menina embruxada. Ela fica bem magrinha, a criança fica bem magrinha, bem sequinha. Um dia tá bem, outro dia tá ruim. Um dia tá boa dos intestino, outro dia já tá com diarréia. Fica magrinha, a criança não desenvolve nunca, nunca. Fica bem magrinha, o leite não, o que toma, a alimentação não leva avante. Sempre magrinha. Eu perdi uma menina, embruxada. Quando eu fui benze ela, numa casa de batuque. Esse senhor na casa era meu cumpadre. Na casa de batuque. Ele tinha batizado a guria, nos santos dele. E aí, a senhora sabe? O meu marido não gostava dessa religião. E uma noite eu tava lá, na sessão, eles iam fazê um trabalho muito forte pra menina, pra segurança da menina. Pra curá ela. E o meu marido foi lá e disse assim, foi buscá e ficou brabo, ficou com ciúme, deu tá lá. E me trouxe, trouxemo a menina, tudo. Mas esse senhor mora lá na Avenida São Pedro, na Alvorada, pra lá um pouco da Alvorada. Tem casa de batuque forte. Andaram prendendo ele, ando fazendo uns troço errado andaram prendendo ele. A polícia prendeu ele. Aí o meu marido foi lá e me trouxe. Brigou comigo na rua e eu ia chorando e tudo, né? Porque eu sabia que a guria ia se salva ali, com aquele serviço, que o meu cumpadre ia fazê da terrera ali, né? Cumpadre Agenor. Aí, senhora sabe o que aconteceu? A guria veio pra casa e já tava melhor. Da meia noite em diante ela começou a piorar. Ele já tinha feito tudo, pra salvá a guria, já tava tudo pronto. Como meu marido vacilou, não quis, deu contra. Ele sendo meu cumpadre, sendo meu amigo, meu cumpadre, eu achei que tava errado, mas a religião dele, como é, os protetor dele não achavam nada disso. Que o meu marido vacilou, ele não podia te vacilado. Eles soltaram tudo. As quartinha que eles tinham prendido pra segurança da guria, eles soltaram. Aí foi. Babau.
\end{abstract}

${ }^{22}$ STEIL, 1999: 97. "Compreendemos como catolicismo popular tradicional um conjunto de crenças e práticas socialmente reconhecidas e partilhadas por um número significativo de católicos, que mantêm uma independência relativa da hierarquia eclesiástica e dos quadros intelectuais a ela ligados. De um ponto de vista subjetivo, podemos entendê-lo como uma maneira religiosa peculiar de um grupo ou de um indivíduo viver a sua fé. Num sentido objetivo, trata-se de um sistema religioso centrado no culto aos santos, compreendido dentro de uma lógica contratual de relações interpessoais, e mantido por um corpo difuso de agentes religiosos leigos.". STEIL, :87.

${ }^{23}$ MALUF, 1993: 148. 
Daquela hora em diante a guria começou a piorar, piorar. No otro dia ela faleceu.

Por vezes, elementos das religiões afro-brasileiras são associados ao discurso, por vezes, a narrativa se aproxima de um kardecismo. Ainda que se possa pensar esse "conhecimento" que Maria diz que é "da natureza, aprendi com a vida", como fundamentado em um catolicismo popular, sincrético ${ }^{24}$, capaz de organizar a diversidade de símbolos num todo coerente, ele só faz sentido na medida em que a prática de Maria faz "irem juntos” ${ }^{25}$ sistemas de crenças mediúnicos e católicos.

"Sobre uma matriz católica comum, o recorte do catolicismo popular é o mais vasto e o menos uniforme. Todos os fenômenos de todos os mundos acreditados podem ser explicados e estabelecem relações entre seres em todos os sentidos.",26

Dentre as religiões mediúnicas, os chamados "bezerra" na ilha, espíritas kardecistas, realizam igualmente essa colagem, do ponto de vista não dos agentes, mas das pessoas que recebem assistência no centro espírita. Do tipo "mesa branca", os "bezerra" orientam, "dão esclarecimento", "iluminam” as pessoas (espíritos "pouco evoluídos") que procuram a pequena casa na ilha, centro de ajuda material (roupas, doações de móveis, "sopa do pobre") assim como de ajuda espiritual para as pessoas atormentadas por obsessões, angústias, problemas em família, visões, vozes estranhas e outros contatos com o "mundo invisível". Pelo fato do espiritismo "explicar tudo", tendo uma doutrina de cunho filosófico, científico e religioso, acolhe todos os tipos de crentes, fiéis, ateus, já que a religião é uma questão de "esclarecimento", conhecimento. Religiões afro-brasileiras, pentescostais e outras são bem acolhidas com a doutrina, que no entanto, é cristã antes de mais nada. ${ }^{27}$ Juventina, antiga moradora da ilha, conta de vozes, vultos e outras coisas que "via" na ilha. Parentes mortos (o marido, o genro) são tema das narrativas, assim como as bruxas, os tesouros enterrados e os lobisomens.

\footnotetext{
"Eu tinha um armázem aqui embaixo, não tinha luz, nós tinha um motor tobata, pra liga a luz. Acredita que o motor ligava sozinho e desligava. É, a mãe dele ali sabe, também da história. Ela não quer vim, é? Te botá ela. Ligava o motor e desligava. Mas a gente via que,
}

\footnotetext{
${ }^{24}$ STEIL, 1999:90. "O sincretismo, na verdade, se coloca como uma tendência que perpassa a trajetória do catolicismo.".

${ }^{25}$ LÉVI-STRAUSS, 1997:62

${ }^{26}$ STEIL, 1999:206

${ }^{27}$ CAVALCANTI, 1990: 147-157.
} 
eu tinha um cunhado que era morto. Morrido aqui, mataram aqui na ilha mesmo. Acho que era ele. Ligava aquele motor e desligava... E eu e o meu marido, nós ficava sentado na frente do armazen, de noite. Acho que era quase meia-noite, também. A gente ficava até tarde, tinha o armazén e tudo. E só tava eu e ele sentado, conversando. Quando passou aquilo, bah. Ele disse assim - Meu Deus! Aí passou uma carroça, um vento. Aí ficou com medo e correu pra dentro. Tinha ninguém na carroça, tinha ninguém, era só um vento.”

Aqui, novamente a idéia de "lugar social do morto" faz sentido, na aproximação entre espiritismo e catolicismo:

“À sua maneira, a cultura católica popular está muito mais próxima da doutrina espírita do que se imagina com frequência. Os espíritos são as almas dos vivos, categoria entendida mais como um princípio ético do que como um princípio metafísico de vida. Depois da morte, os espíritos são tipos de almas, são o sujeito vivo do morto. São sujeitos não-terrenos, mas ainda personalizados, quando são parentes ou conhecidos; ou são "alma penada", "assombração", quando aparecem como vultos de mortos a quem não se pode atribuir uma identidade legítima.,"28

Assim, Maria nos narra:

\footnotetext{
"Ali aparecia uma senhora muito bonita de vestido comprido que ela aparecia com um buquê de flor na mão e uma vela acesa, uma luz, aquela luz muito linda que ela aparecia. Tão bonita, assim, parecia uma Nossa Senhora, que ali diz que foi cemitério uns tempos atrás, né?"
}

Ainda que eu não tenha tomado contato com nenhum informante praticante de alguma religião afro-brasileira, a umbanda e o batuque são religiões que também aparecem, na forma de seus símbolos, deuses e práticas, nas falas dos demais informantes, como já foi apresentado. Sua presença na ilha encontra-se demonstrada, portanto, no campo de trocas religiosas de Porto Alegre, da qual a ilha faz parte. E da mesma forma que com o espiritismo, se encontra próxima de um catolicismo popular, em que o culto de Nossa Senhora Aparecida, e Nossa Senhora dos Navegantes, mediada pela relação com as águas e seus orixás, é o melhor exemplo. A Festa de Navegantes envolve, todos os anos, muitos devotos e pessoas de todas as crenças (exceto as evangélicas) das ilhas, no 2 de fevereiro.

\footnotetext{
${ }^{28}$ BRANDÃO, 1986: 187.
} 
Centrando o debate, portanto, em torno da religião popular, de um sistema popular de crença, poderia inserir-se as idéias de Otávio Velho ${ }^{29}$ quanto a existência de um pré-texto, uma cultura bíblica como esquema simbólico de interpretação sobre o qual se inscrevem os "textos" de outras "culturas" religiosas, no Brasil. Uma reatualização dos significados dos símbolos e imagens católicas, que demonstram a força de permanecerem presentes, mesmo quando encontram-se com outros sistemas de crença no meio popular. "Algo do significado passa para o significante", um significado justamente inatingível, desconhecido, repousando no mistério, naquilo que Lévi-Strauss chama de "significado flutuante",30, como forma de permanência do símbolo representando esse significado. As bruxarias viram "macumbaria", os espíritos "desencarnados" viram "aparições". Todos viram "artimanha do demônio". Mas as bruxas seguem sendo bruxas, as aparições continuam aparencendo, e os lobisomens... bem os lobisomens, não os coloquei ainda nessa história toda, por que são essas as histórias que condensam o máximo de expressividade de "assombro", e de unidade nas narrativas das pessoas. Emergidos de um mesmo fundo de sentido do catolicismo popular (o lobisomem é um ser sobrenatural, entre o humano e o animal), esses "causos" trazem um saber popular sobre as particularidades da sina do amaldiçoado, das atitudes a ter com ele, de um tom no contar da história, enfim, possuem características estruturais.

Nos conta Geni: “Ah, lobisomem eu conheço, lá fora. Já vi um lobisomem, lá fora. É?
Lá em Santo Amaro. Aqui não, lá em Santo Amaro. Como é que era,
lá? Lobisomem é uma pessoa que se vira num cachorro. Coisa
interessante. Uma vez o meu pai tava bebendo num armazen. Longe
da nossa casa. Muito longe. O armazen lá era como daqui ao centro.
Leva quase um dia pra chegar no armazen lá fora. Agora tá tudo
mudado, né? Mas no meu tempo, quando eu nasci lá e me criei. O
armazen que nós comprava era o antigo Cláudio. Tinha que i de a
cavalo. A pé não podia, tinha que se a cavalo. E o meu pai tava
bebendo e os companheiro dele, de bebida, disse - óia, tu tá até essa
hora no armazén aí vai aparece o lobisomem pro senhor quando tive i
pra casa. Aí o pai se mandava com um revorver dum lado, e um
facão, uma adaga, aquelas adaga de brigadiano. Tava sempre com
aquele revorver e aquela adaga, sempre, sempre com o revorver. Mas
não é que o véio não foi pra casa e o lobisomem não deixou o velho ir
pra casa? Quando ele ia chegando perto de casa aquele cachorrão,
deitado, sentado no meio da rua. Bãita dum cachorro preto. E, e o
véio temeu. Não passo. Pego o revorve deu um tiro ele nem se mexeu.
Deu otro tiro e não adianto. O véio, sabe duma coisa? Vo volta pro
armazén, deixa clarea o dia pra ir pra casa. Não pode passa pra casa.
E o lobisomem esse era um vizinho nosso. Do lado da nossa casa. Aí.

${ }^{29}$ VELHO, O. 1987: 22.

${ }^{30}$ LÉVI-STRAUSS, em MAUSS, 1974: 34-35. 
O pai deixou clarear o dia foi pra casa. Tem a hora de fica na rua, esse lobisomem. Aí a vizinha disse assim, uma otra senhora disse assim, o senhor vai na casa dele e faz, intima ele e faz ele abri a boca, pra os senhor ve os fios do cobertor, da manta minha mãe, estendeu o cobertor, ele embocou o cobertor ficou os fio nos dente. Olha, e o pai foi lá e viu e a mãe também. Tava os fio do cobertor nos dente. E eu espiei e ele tava lá roçando no cobertor. Trepo numa árvore, perto da nossa casa, do velho esse. Aí o velho chamou ele e descobriu o segredo dele. Aí ele não, tratou de se mudar, e não virou-se mais lobisomem, né? Aí ele teve que se muda de lá. E o pai não voltou de lá. E eles riam do pai, os amigo - não te disse que o lobisomem ia te aparecer. E ele voltou pro buteco e ficou até o clarear pra poder ir pra casa. Lá era muito longe, as venda. Sempre tinha lobisomem, bruxa.

\section{FAZERES}

\subsection{Da arte de dizer}

Se até agora procuramos analisar as estórias, as narrativas, em relação a um saber popular, religioso, a partir das práticas religiosas de seus narradores, proponho agora analisá-las enquanto um fazer. Fazer no sentido que lhe confere Michel de Certeau, de que "a arte de dizer é uma arte de dizer e uma arte de pensar" na ação humana, numa prática, um conhecimento do mundo. Assim como Evans Pritchard $^{32}$ propoz pensar-se a bruxaria como uma forma de conhecimento do mundo ${ }^{33}$, proponho pensar a arte de narrar também como prática de composição do tempo, de mediação entre tempo humano, percebido, pré-configurado, e narrativa, tempo configurado, seguindo as idéias de Paul Ricouer ${ }^{34}$. Proponho, portanto, pensar o contar dessas histórias como um sistema de comunicação, onde um conhecimento do mundo (que não se esgota nos sistemas de crença, mas antes se alimenta deles) é o grande instrumento de transmissão desse saber, de uma tradição oral.

Na palavra do homem ordinário, desfia-se uma arte, de golpes, em que o que importa não é tanto o objeto do discurso, mas o efeito que causa pela maneira em que é narrado, pela forma em que o dito aproveita a ocasião para introduzir uma surpresa. Paul Ricouer entende essa arte como a arte da tecitura da intriga, através de uma précompreensão da ação, de seu significado, da força de sentido que encerra em si mesma, e da configuração das ações humanas em sua sucessão no tempo. Destina-se a um leitor, a um espectador, e no presente caso, a um ouvinte, na forma de uma supresa, numa estrutura de concordância e discordância.

\footnotetext{
${ }^{31}$ CERTEAU, 1994:152.

${ }^{32}$ EVANS-PRITCHARD, 1956.

${ }^{33}$ GEERTZ, 1983:118.
} 
"o tempo torna-se humano na medida em que está articulado de modo narrativo: em compensação, a narrativa é significativa na medida em que esboça os traços da experiência temporal" 35

É preciso primeiro um pré-conhecimento da ação e do mundo da ação (mimese I) para compreender o que ocorre com o agir humano no mundo, o caráter temporal da experiência. Configurar esse tempo percebido em tempo narrado é tecer a intriga, desfiar essa história (mimese II), no agenciamento dos fatos. Concordância com a sucessão do "e aî", "então", com o que se espera com o desenrolar da ação, e com a discordância, o que não se espera, o infortúnio, a sorte, a virada, que no entanto, é o engendra o sentido da história. O reconhecimento dessa trama pelo ouvinte (mimese III), e o seu efeito, é que motiva a configuração do tempo.
"a resposta emocional do espectador é construída no drama, na qualidade dos incidentes destruidores $\mathrm{e}$ dolorosos para os próprios personagens... o "surpreendente" - cúmulo do discordante - são então os golpes do acaso que parecem acontecer de propósito." 36

Uma lucidez que instaura o herói na sua verdade e o espectador no conhecimento dessa verdade. A obra exibe um mundo do qual o leitor apropria-se, um mundo cultural, uma tradição.

Maria conta:

\begin{abstract}
"aí uma noite meu marido fazia jogo de pife, em casa, então eu sempre ficava acordada, pra faze os café pros jogador, alguma coisa, né? Aí eu saí pra fora e ele saiu junto. Aí a gente se tratava negra, negra. Negra, vem cá correndo, eu digo que que é? E tinha o rener, os fundo do rener, e tinha um portão, mas tinha um morrinho que passava assim, era cheio de maloquinha pra cá, aí quando ele olha diz assim Olha lá nega, olha lá ligeiro o que que é? Ah, pára, olha ligeiro, que que eu vou olhá? Olha lá que tu vai te apavorá. Quando eu olho assim eu vi aquele cachorro branco, aí me apavorei, aí mesmo que me apavorei mais, né? Aí tava aquela mesa cumprida assim, tinha a minha casinha e tinha uma área grande que era cozinha e área ali e eles tavam tudo jogando, né? Inclusive tinha um mesmo rapaz que era o mesmo nome dele, Adaír. E ele tava assim jogando, dizia, aí vem a minha, bota a minha, larga a minha. Aí diz
\end{abstract}

\footnotetext{
${ }^{34}$ RICOUER, 1994.

${ }^{35}$ RICOUER, 1994: 15.

${ }^{36}$ RICOUER, 1994: 72.
} 
assim Ô Tocaio vem cá ligeiro! Ah Adair, me deixa, deixa, eu vou ganhar agora. Aí diz assim, mas vem que eu quero te mostrar uma coisa. Mas que que é rapaz, mas que coisa tão importante é essa. Aí largo as carta, fez assim, boto as carta na mesa, óia, não mexe aí que eu já volto. Aí foi lá, boto a mão. Bah Tocaio! Pra que tu me chamô? Bah cara, olha lá! Mas era um cachorro comprido, acho que tinha uns treis metro, com a cola bem comprida, parecia um algodão. A cabeça enorme, e ele ia assim, a passo... movimento nenhum fazia ele olhar pra trás, que fosse fazê ele olhá, não, por mais barulho que fizesse, não. A gente falô, ali, saiu pra olha, ai, eu me arrepiava todinha, como quem quis, aí o resto da noite não podia dormir, com medo né? Aí o cachorro se foi, se foi, sumiu. Foi direto às casinha, às maloquinha que tinha ali. Dali ele sumiu, né? A gente não se viu mais eles. Isso que eu vi né?Era lobisomem, era um lobisomem mesmo."

Enquanto narrava essa história, os alunos da oficina de vídeo, e seus professores, ficavam de ouvidos e olhos atentos. Maria mostrava no tom de voz, nas pausas que fazia, na maneira como introduzia cada novo elemento" ("vem cá que eu vou te mostrar uma coisa"), uma performance nos gestos que fazia na recriação espacial da história ("olha lá cara!") e na imitação das ações ("tava assim jogando”, "boto as mão na cabeça. Bah Tocaio”) e como sustenta até o final a confirmação do que espera o ouvinte, desde o início da história: “era lobisomem, era lobisomem mesmo.”. Penso em performance, segundo as idéias de Victor Turner ${ }^{38}$, um indivíduo que desempenha uma performance, uma complexa sequência de atos simbólicos, expressando poeticamente, estetizando criativamente uma tradição para um público, com a devida competência. As histórias de lobisomem apresentam claramente, assim como as outras, de tesouros enterrados, assombrações, a mediação de um saber onde os sistemas de crença estão envolvidos, uma arte de contar e de ouvir histórias, em que o narrador sinaliza ao ouvinte que vem aí uma história, no que Turner chamad de liminal caracteristics: "Ah, lobisomem eu conheço, já vi lá fora.”, “as bruxa? Sabe o que elas fazem?”, "Uma bruxa, que fez mal pra mim, uma bruxaria. Mas ela trabalha com o demônio. Eu conheci pessoas assim. Eu era guri, cuida bem: uma história verídica que comigo aconteceu.".

\footnotetext{
37 “A ocasião, apreendida quando surge, seria a própria transformação do toque em resposta, "uma inversão" da supresa esperada sem ser prevista: aquilo que o acontecimento inscreve, por mais fugitivo e rápido que seja, é devolvido, é-lhe devolvido em palavra ou gesto. Lance a lance.". CERTEAU, 1994:164.

${ }^{38}$ TURNER, 1985.
} 
Carlos Steil, em sua etnografia entre os romeiros de Bom Jesus da Lapa ${ }^{39}$, propõe a pensar a tradição oral de um santuário de peregrinação, intepretar as muitas histórias que os romeiros contam de milagres no santuário como um sistema de comunicação, onde a tradição de um catolicismo popular tradicional encontra seu espaço na disputa com um catolicismo erudito, e onde os romeiros trocam, na oralidade, a sua tradição, apoiados numa tradição bíblica de imagens sagradas.

“O santuário da Lapa é depositário de uma memória bíblica da qual os romeiros se reapropriam continuamente, através das romarias, que funcionam como um processo de aprendizagem que se efetua num clima de jogo e celebração."40

A memória, na oralidade, aparece como uma forma de transmissão de um conhecimento do mundo. E encontra-se apoiada num campo semântico, onde não há um significado direto para cada história que é contada muitas vezes, mas um "mundo que é aberto ao leitor (ouvinte)" ${ }^{41}$ que incorpora e transmite novos significados.

Entre os crentes, percebia que a oralidade é também a grande arma da transmissão do conhecimento das escrituras entre analfabetos. Num Sábado de jejum e estudo da Bíblia, de oração, acompanhei os crentes em seus louvores, cantos, e testemunhos de fé. Enquanto tentavam converter o jovem antropólogo, que mesmo estando ali por motivos de pesquisa, "que não entrou na Igreja por acaso", liam em voz alta textos decorados da Bíblia, repetiam seus versos, mas era no momento dos testemunhos que eu via aqueles crentes se apropriarem de um conhecimento, e de um lugar de sabedoria que a oportunidade do púlpito da igreja lhes conferia, de narradores a uma platéia. Laci, minha informante, me viu contente entrar na Igreja, e aproveitou minha presença para dizer que eu era "um amigo" que ouvia suas histórias das ilhas, e assim, narrou muitas das histórias que já havia me contado, para o público, como prova de sua fé. Da mesma forma, outras histórias de viciados, da própria conversão de cada um, de milagres, de lutas contra orixás e demônios, eram contadas, de um caso de bruxaria como o narrado por Cláudio a uma simples compra de uma geladeira, em que Jesus "aprovava o crediário" da devedora pecadora. Um saber de fé, na Assembléia de

\footnotetext{
${ }^{39}$ STEIL, 1996: 99. "Mais do que uma referência ao imponderável, que irrompe na ordem natural do mundo, os milagres podem ser lidos como textos. São unidades ou frases significativas, dentro de uma narrativa, que busca situar as ações humanas num mundo "re-encantado". São interpretações que apontam para o caráter ficcional de qualquer conhecimento. E, desse modo, percebe-se que os sentidos são construídos no ato narrativo..."

${ }^{40}$ STEIL, 1996: 157.

${ }^{41}$ RICOUER, 1994: 110.
} 
Deus, encontra na oralidade o seu grande instrumento de transmissão em contextos populares. Seus crentes, são todos, excelentes narradores, e passam adiante, como arma de sua força e fé, as muitas histórias de salvação que ouvem e vivem. Me contava Geni, entre um caso de assombração e uma história de lobisomem:

Tinha um, que.. foi lá na Alvorada. Ele ia passando, vinha passando, parou um carro deles na frente da Igreja, lá na Alvorada, não quero menti, parece que na Alvorada ou Restinga. Paro um carro na igreja, tava lotadinha de gente. Aí o chefe deles pediu - desce. Vai lá, que nós comecemo, nós vamo atrás de ti. Vai lá, mata o portero e da um tiro no, entra e mata o, lá em cima, dá um tiro nele que nós vamo atrás e, e carcemo os otro no revórver. E nesse dia que entrou esse era uma mulher que tava na porta, cuidando a porta, chega a me arrepiar, e a mulher levantou a Bíblia pra cima. E orô. E ele entrou. Quando ele chegou na frente do púlpito o revorver caiu no chão, o revorver dele, caiu da mão. Na frente do irmão que tava pregando. $E$ os outros, viram aquilo, desceram e convidaram ele pra ir embora. Mas quando eles saíram da igreja, já tavam no carro pra ir embora, a polícia veio atrás deles, não conseguiram se escapar. A polícia pegou eles. Ele puxou o revorver pra matar o irmão que tava pregando a palavra de Deus e caiu o revorver no chão. O irmão mandou ele juntar o revorver e sentar, né? E ele sentou. Aí ele ficou sentado ouvindo. Mas quando ele entrou a irmã viu, a irmã Clara, né, o assaltante. Ele mesmo pregando na entrada do púlpito, dentro da Igreja. Aí ele disse que se entregou a Jesus e nunca mais quis saber dessas coisas. E os outros, aqueles que não quiseram entrar, os outros, aqueles dois entraram, foi dois que veio, se salvaram, e os outros riscaram mas a polícia pegou, chegou atrás deles. Aí levaram, $e$ aqueles dois foram liberto, nunca mais foram assaltante, entregaram os revorver. Coisa muito linda.

Na capacidade da ação de ser narrada e na necessidade de narrá-la, o crente tece a intriga de uma salvação ${ }^{42}$ e de uma cura pela palavra, com a devida "eficácia simbólica"43. Uma catharsis, uma purificação, segundo Ricouer, que “...tem sua sede no espectador. ... Consiste pois na transformação em prazer da pena inerente a essas emoções. Mas essa alquimia subjetiva é também construída na obra pela atividade mimética."44

\footnotetext{
${ }^{42}$ DURKHEIM, 1968:565. "Mas os crentes, os homens que, vivendo a vida religiosa, possuem a sensação direta daquilo que a constitui, objetam que essa maneira de ver, que ela não responde à sua experiência cotidiana. Com efeito, eles sentem que a verdadeira função da religião não é a de nos fazer pensar, de enriquecer o nosso conhecimento, de acrescentar às representações que nós devemos à ciência, representações de uma outra origem e de um outro caráter, mas de nos fazer agir, de nos ajudar a viver. $\mathrm{O}$ fiel que se comunica com o seu deus não é apenas um homem que enxerga as novas verdades que o descrente ignora; ele é um homem que pode mais".

${ }^{43}$ LÉVI-STRAUSS, 1996:215-237. Não é também uma narrativa o texto de Lévi-Strauss "A Eficácia Simbólica", na medida em que produz, no leitor, o efeito de uma canção medicinal no doente, por intermédio da palavra do xamã (e do antropólogo)?

${ }^{44}$ RICOUER, 1994:83.
} 
E também nos muitos casos de mistério, de "assombro", e de seres fantásticos, um mundo fantástico, um mundo cultural ${ }^{45}$ é oferecido ao ouvinte, um mundo em que nada é por acaso, e as ações todas tem um sentido de acontecerem, na ordem em que acontecem, e mesmo aquilo que não é possível compreender, é verossímel justamente na impossibilidade da explicação.

"Ora, o que designam a realidade presente (e passada), a opinião e o dever-ser, senão o próprio domínio daquilo em que podemos crer? ... É preciso preferir o que é impossível mas verossímel ao que é possível mas não persuasivo" "46

A poesia, a poética da arte de dizer é com efeito, um "fazer". "O artesão de palavras não produz coisas, mas somente quase-coisas, inventa o como-se."47. E essa tradição narrativa, uma tradição narrativa do ocidente, arte de manipular concordância e discordância na elaboração das surpresas e reviravoltas, nasce do trabalho da imaginação criadora sobre os gêneros e obras conhecidos, media saberes. A palavra do crente, do católico com fé no seu santo, do espírita com seu esclarecimento, não se esgota no sistema de crença do qual se origina e ao qual se refere, mas algo de inovação escapa num jogo de sedimentação (das obras e gêneros conhecidos) e da inovação (na geração de novas obras e gêneros).

Ensinando o universal, restituindo o tempo do agir e do padecer (mimese III) ${ }^{48}$, o narrador possibilita uma interseção entre o mundo do texto e o mundo do ouvinte, em que

\footnotetext{
"o que é comunicado, em última instância, é, para além do sentido de uma obra, o mundo que ela projeta e que constitui seu horizonte. Nesse sentido, o ouvinte ou o leitor o recebem segundo sua própria capacidade de acolhimento que, também ela, define-se por uma situação ao mesmo tempo limitada e aberta a um horizonte de mundo." 49
}

\footnotetext{
45 RICOUER, 1994:85. "Existe entre a atividade de narrar uma história e o caráter temporal da experiência humana uma correlação que não é puramente acidental, mas apresenta uma forma de necessidade transcultural.".

${ }^{46}$ RICOUER, 1994: 82.

${ }^{47}$ RICOUER, 1994:81.

${ }^{48}$ RICOUER, 1994: 110.

${ }^{49}$ RICOUER, 1994, 119.
} 
Partilhar uma experiência, ter algo a dizer a partir da autoridade que a memória confere ao narrador, é completar no ouvinte o círculo hermenêutico da narrativa. $\mathrm{O}$ lembrar depende de quem ouve, a lembrança depende da circunstância, ela é sentida do outro.

“... implica em primeiro lugar a mediação de um saber, mas um saber que tem por forma a duração de sua aquisição e a coleção interminável dos seus conhecimentos particulares... Este saber se faz de muitos momentos e de muitas coisas heterogêneas. Não tem enunciado geral e abstrato, nem lugar próprio. É uma memória, cujos conhecimentos não se podem separar dos tempos de sua aquisição e vão desfiando as suas singularidades." 50

E quando a lembrança é sentida do outro, é importante dizer, pode-se pensar no papel de ouvinte do antropólogo. Esse papel comporta, é claro, uma construção de objeto de pesquisa, as pessoas só contam essas histórias porque o antropólogo quer escutá-las, quer seja nos momentos em que havia uma equipe de gravação, composta também por adolescentes locais, quer seja no momento em que um antropológo parte para investigar a memória da ilha, suas transformações, e o assunto surge na referência, por vezes, a minha entrada no campo com esse vídeo, e por vezes, na própria alusão à uma memória do espaço. O lugar da equipe ou do antropólogo ouvinte, é o lugar do leitor a que se refere Ricouer, o lugar da interpretação, sem a qual, o narrador não consegue tecer sua narativa. E nesse caso, trata-se de um percurso pela trajetória social dessas pessoas, por seus diferentes pertencimentos a diferentes locais, inclusive a ilha, pelas diferentes formas de se apropriarem dos espaços, no tempo, na maneira como recuperam, na entrevista, suas lembranças, suas estórias.

\section{Conclusão}

\footnotetext{
"o narrador entra na categoria dos professores e dos sábios. Ele dá conselho - não como o provérbio: para alguns casos - mas como o sábio: para muitos. Pois lhe é dado recorrer a toda uma vida. (Uma vida, aliás, que abarca não só a própria experiência, mas também a dos outros. Àquilo que é mais próprio do narrador acrescenta-se também o que ele aprendeu ouvindo.) Seu talento consiste em saber narrar sua vida; sua dignidade, em narrá-la inteira. $O$ narrador é o homem que poderia deixar a mecha de sua vida consumir-se integralmente no fogo brando de sua narrativa." 51
}

\footnotetext{
${ }^{50}$ CERTEAU, 1994:157-158.

${ }^{51}$ BENJAMIN, 1980: 74.
} 
Tenho, eu também, a minha crença. Creio no narrador, na arte de narrar. E creio na fé, ou na crença, no sentido de sua prática, de apostar no ato de crer, e nem tanto num objeto específico de crença $^{52}$. Dentro da característica da modernidade, de "reencantamento do mundo", em que "formas modernas de crer"53 podem ser pensadas, propuz pensar a figura do crente, do agente religioso, junto a figura do narrador. Pastor evangélico, benzedeira, crente, ou simplesmente alguém que tem fé, não inseri por acaso, nesse texto, a voz de velhos, que a partir de uma memória, de uma trajetória pessoal e uma lógica biográfica, são "cada um, a seu modo e com as palavras de sua crença, sujeitos de conselho e de juízo... Eles são finalmente os mestres de crença."54

Reconhecidos pela comunidade, por uma platéia, ou por um ouvinte no contar de uma história, são portadores de uma sabedoria popular, articulam, a partir de uma tradição bíblica comum, como sugere Otávio Velho ${ }^{55}$, ou de uma tradição narrativa comum, como propõe Ricouer, os muitos sistemas de crença, religiosos ou não, que circulam pela Ilha Grande dos Marinheiros. Sabem dar os nomes e prescrever as regras de nominação, e conhecem as normas entre seres do mundo e seres sobrenaturais, nominados de muitas maneiras.

Fiz também a minha colagem, o meu percurso por essas crenças todas, no sentido de incorporar, integrar e juntar mais do que em restringir, separar e especificar cada sistema religioso. E professo aqui a minha fé na Antropologia, "gênero confuso", como diria Geertz ${ }^{56}$, sendo aqui também um narrador que transmite, ainda que pela escrita, e não pela oralidade, um mundo outro ao leitor, onde as coisas não acontecem por acaso, e tudo tem a sua explicação, ainda que o recurso do mistério, por sua dificuldade em ser explicado, seja geralmente, a melhor explicação.

E pela lógica afetiva, que parece prezidir a lógica religiosa na modernidade, procurei aqui também inscrever a ação humana (a do antropólogo e seus informantes) como forma de cura do mal-estar do mundo ${ }^{57}$. Como disse, em uma pesquisa ainda em andamento, procurei articular as práticas religiosas dos informantes, os sistemas de crença a que se colocam filiados, e as práticas da arte de dizer, das narrativas que

\footnotetext{
${ }^{52}$ CERTEAU, 1994: 278

${ }^{53}$ ORO, 1997.

${ }^{54}$ BRANDÃO, 1986: 151.

${ }^{55}$ VELHO, O. 1987: 23.

${ }^{56}$ GEERTZ, 1997: 33-57.

57 VELHO, O. 1994. "A sociedade (e o conhecimento) simplesmente não possui mais, num sentido positivista, fundamento algum".
} 
contam. Através de um estudo da memória coletiva das ilhas, e especificamente da Ilha Grande dos Marinheiros, é possível articular esses saberes e fazeres nas muitas trajetórias que se cruzam, formando um saber e uma estória das transformações da paisagem local, habitada por lobisomens, assombrações, bruxas, crentes, narradores, e também, por antropólogos.

\section{REFERÊNCIAS}

"Consolidação do Parque Estadual Delta do Jacuí - reavaliação das condições sócio-econômicas da população e situação atual de ocupação e uso do solo do Parque”, Pró-Guaíba e METROPLAN, Governo do Estado do Rio Grande do Su, 1999.

BENJAMIN, Walter. “O Narrador” em “Os pensadores”. São Paulo, Abril Cultural, 1980.

BRANDÃO, Carlos Rodrigues. “Os deuses do povo”. São Paulo, Brasiliense, 1986.

CAVALCANTI, Maria Laura Viveiros de Castro. "Espiritismo" In "Sinais dos Tempos: Diversidade Religiosa no Brasil" - Rio de Janeiro, ISER, 1990.

CERTEAU, Michel de. A Invenção do Cotidiano - 1: Artes de Fazer. Petrópolis, RJ. Vozes. 1994.

EVANS-PRITCHARD “Bruxarias, Oráculos e Magia entre os Azande”, Barcelona, 1995.

FERNANDES et alli. "Novo nascimento. Os evangélicos em casa, na Igreja e na política.” Rio de Janeiro, Mauad, 1998.

GEERTZ, C. "O Saber Local - novos ensaios em antropologia interpretativa”, Petrópolis, Vozes, 1999ROLIM, Francisco Cartaxo. "Assembléia de Deus” In "Sinais dos Tempos: Diversidade Religiosa no Brasil" - Rio de Janeiro, ISER, 1990.

LÉVI-STRAUSS. "Antropologia Estrutural”. Rio de Janeiro, Tempo Brasileiro, 1996.

LÉVI-STRAUSS. "Pensamento Selvagem”. Campinas, Papirus, 1997.

MALUF, Sônia. "Encontros Noturnos - bruxas e bruxarias na Lagoa da Conceição." Florianópolis, Rosa dos Tempos, 1993.

MAUSS, M. "Sociologia e Antropologia”, v.1. São Paulo, EDUSP/E.P.U., 1974.

ORO, Ari Pedro. "Modernas Formas de Crer" In: Revista Eclesiástica Brasileira. Petrópolis, Vozes, N. 225, 1997.

RICOUER, Paul. Tempo e Narrativa. Tomo I. Campinas, SP. Papirus. 1994

SCHAMA, Simon. "Paisagem e Memória”. São Paulo, Companhia das Letras, 1996.

STEIL, C. "Catolicismo popular tradicional e ação pastoral: desafios e perspectivas no contexto da cultura contemporânea",

STEIL, Carlos. "O sertão das romarias”. Petrópolis, Vozes, 1996.

TURNER, Victor. "The Antropology of Peformance", In "On the Edge of th Bush Anthropology as Experience." Tucson, Arizona,The University of Arizona Press, 1985.

VELHO, G. "Individualismo e Cultura”, Rio de Janeiro, ZAHAR editores, 1981.

VELHO, O. "Religião e Modernidade: roteiro para uma discussão." In: "Anuário Antropológico 92. Rio de Janeiro, Tempo Brasileiro, 1994.

VELHO, O. “O Cativeiro da Besta-Fera” In Religião \& Sociedade n. 13/1, março de 1986, p. 4-27. 